\title{
Wildlife trafficking in the Internet age
}

\author{
Anita Lavorgna
}

\begin{abstract}
There is a broad consensus that the Internet has greatly expanded possibilities for traditional transit crimes such as wildlife trafficking. However, the extent to which the Internet is exploited by criminals to carry out these types of activities and the way in which it has changed how these crimes are carried out remains under-investigated. Based on interviews and investigative cases, this paper shows the possibilities offered by a crime script approach for understanding what kind of criminal opportunities the Internet offers for conducting wildlife trafficking and how these opportunities affect the organization of this transit crime, as concerns both the carrying out of the criminal activity and the patterns of relations in and among criminal networks. It highlights how Internet-mediated wildlife trafficking is a hybrid market that combines the traditional social and economic opportunity structure with that provided by the Internet.
\end{abstract}

Keywords: Wildlife; Internet; Organised crime; Transit crime; Script analysis; Criminal opportunities

\section{Introduction}

The commercialization of the Internet, like any other technological change, has modified the environment in which crime operates. The benefits from using the Internet are certainly not lost on criminal networks involved in socalled transit crimes-i.e., criminal trafficking activities (Kleemans 2007) $^{\mathrm{a}}$. In cyberspace criminals can take advantage of more rapid and secure communications. However, as regards the relationship between traditional transit crimes and the Internet, apart from the vague statement that the Internet is a facilitator of organized criminal activities (EUROPOL 2011), so far only a few traditional transit crimes-such as drug and sex trafficking-have been subject to systematic analysis. For instance, it has been underlined that criminal networks involved in drug trafficking use the Internet to deliver their products more effectively, to communicate through encrypted messages, or to counter the work of law enforcement agencies through digital attacks (Walsh 2011; EMCDDA 2013), while human traffickers exploit the Internet to both recruit and exploit victims (Hughes 2002; Sykiotou 2007).

The current study considers how the Internet facilitates wildlife trafficking, which is broadly defined here as the illegal trade of any wild plant or animal (live specimens, dead parts, and derivative products) from the moment of

Correspondence: anita.lavorgna@unitn.it

School of International Studies - University of Trento, via Tommaso Gar 14, 38122 Trento, Italy the initial capture, breeding, or harvesting to purchase by the final buyer. After a brief overview of the offline criminal market in wildlife, a script scheme is used to highlight the opportunity structure the Internet offers to carry out wildlife trafficking and to give a more comprehensive and precise description of how actors involved in this criminal activity behave in cyberspace.

\section{The criminal market in wildlife}

Wildlife trafficking is a transit crime that has far-reaching implications for society. Not only does it severely affect the environment by impacting biodiversity, it also hinders social and economic development in many communities (Warchol 2004; Sollund 2011). Furthermore, wildlife trafficking represents an increasing threat to national and global security (IFAW 2008) being partially run (sometimes in parallel to other transit crimes) by sophisticated crime syndicates that use the profits for terrorism and guerrilla insurgency (IFAW 2008; Dalberg 2012). Wildlife trafficking can also pose risks to global health and it harshly impacts animal care and conditions (Dalberg 2012).

The black market in wildlife is estimated from 6 to 10 billion dollars per year (Warchol 2004; Dalberg 2012), and it allows for huge possibilities for profits. Most plants and animals are trafficked from developing countries to the Western world, and the European Union is considered the top global importer by value of wildlife, ranging from live reptiles and birds to caviar and reptile skins

\section{黑 Springer}


(Engler and Parry-Jones 2007). Surprisingly, wildlife trafficking has generally received relatively little attention from criminologists, although there have been a few exceptions. Moreover, wildlife crimes have low priority on the law enforcement agenda (IFAW 2008). Most governments consider it as a "mere" environmental issue, and as a consequence investigations are generally scarce and sparse (Zimmerman 2003). As such, there are minimal consequences for criminals for perpetrating wildlife trafficking, making it a high-profit, low-risk criminal business.

The demand for wildlife products is considerably influenced by culture and depends on different consumer groups (Dalberg 2012). On the one hand, some wildlife products are smuggled in local and international markets because of their perceived value in traditional medicine and in traditional (or exotic) gourmet dining - as in the case of rhino horn, tiger bones, shark-fin, and beluga caviar-or because they are considered as a status symbol, for example for private zoos in Saudi Arabia or the villas of Colombian drug lords and Camorra bosses (Zimmerman 2003; Warchol 2004; Legambiente 2010; Sollund 2011). Plants and animals of all types and values are also poached for private collectors and pet shops worldwide, and the demand is fueled by biomedical laboratories for scientific purposes, by hunters preparing for canned hunt or falconry, and by fur and skin dealers (Zimmerman 2003; Wyatt 2009; Sollund 2011).

Regarding the supply side, there are considerable variations in the typologies of the offenders involved-ranging from individual subsistence hunters to sophisticated crime syndicates-depending on the market demand and on the different species traded (Warchol 2004; IFAW 2008). Zimmerman (2003) has identified three main types of criminals involved in wildlife trafficking: local farmers trying to supplement their incomes, mafia-style groups operating in developing countries, and international smuggling rings. Evidence suggests that most wildlife trafficking, particularly in regards to the initial part of the market supply chain, is carried out by individuals; opportunistic villagers who try to supplement their income and professional trappers. However, in other stages of the trafficking chain and especially in international trades higher levels of sophistication and several organizational layers may be required (Warchol et al. 2003; Wyatt 2009; Pires and Clarke 2012). The involvement of organized criminal groups (as well as militias and terrorist groups) in wildlife trafficking has received increasing attention, to the point that a recent report from the International Fund for Animal Welfare stated that "the global illegal trade in wildlife crime is organized crime" (IFAW 2008: 7, italic in original). While this affirmation appears probably too deterministic to describe the multifaceted reality, it is true that there are proxy indicators suggesting that sophisticated criminal networks are exploiting wildlife as source of profit, especially in its most lucrative areas such as caviar smuggling (Cook et al. 2002; Cooper 2006; IFAW 2008) and the fur trade (according to two interviewees). First, they can easily incorporate these smuggling activities with other types of contraband by using pre-established trafficking routes or even by employing wildlife as currency for money laundering (Cook et al. 2002; Zimmerman 2003; IFAW 2008). Second, the extent of wildlife trafficking and the need of facilitators-such as forgers to make fake export/import documents and businessmen in the transport sector-imply the need of organized criminal structures (IFAW 2008; Wyatt 2009; Pires and Clarke 2012).

From a legal point of view, wildlife trafficking is mainly regulated by the 1975 UN Convention on the International Trade in Endangered Species of Wild Fauna and Flora (CITES). By 2013, 178 countries had signed onto the treaty. CITES provides three levels of protection for endangered species (Warchol 2004; IFAW 2012): species listed on Appendix I are considered highly endangered so that their trade is banned; species included on Appendix II are considered vulnerable so that their export is strictly restricted; species listed in Appendix III are protected in at least one country, which has asked other CITES parties for assistance in controlling the trade $\mathrm{e}^{\mathrm{b}}$. Overlapping with wildlife trafficking is the illegal trade in pets. Many exotic species are increasingly considered as pets in Western markets, and the distribution channels are often the same (for instance, pet stores). In this study, trafficking in pets is considered alongside wildlife trafficking. When differences arise, they will be specified in the analysis.

A significant amount of wildlife trafficking is reportedly dependent upon the Internet (Williamson 2004; IFAW 2005, 2012; WU 2007; Troiano 2011; Interpol 2013) ${ }^{c}$. However, as regards criminological research, apart from some general claims that the Internet facilitates wildlife trafficking, so far scholarly attention has not focused on the online trade of animals and plants. A substantial gap in the literature can be identified concerning what kinds of criminal opportunities the Internet offers for criminal networks running wildlife trafficking and how these opportunities affect the organization of this transit crime. This entails identifying at what specific phases of wildlife trafficking and for what purpose the Internet is used as a crime facilitator, as well as understanding the consequences that the Internet has on the way in which this criminal activity is carried out.

\section{Opportunity as cause of crime: Origins and evolution of script analysis}

Environmental criminology-considered here more as a multifaceted framework rather than as a rigorous theoretical model (Felson and Clarke 1998) - and the practical 
application of situational crime prevention have emphasized the importance of criminal opportunities-i.e., "what provides both the occasion (the objective condition) for the action and the temptation (the condition perceived as favorable)" (Mayhew et al. 1976: 7, emphasis in the original). In order to identify criminal opportunities and, as a consequence, potential points of intervention, situational crime prevention teaches us to think about a crime by breaking it up into the sequential phases of its commission. Cornish (1994) elaborated the concept of "crime scripts" to describe the essential stages of a criminal activity, making the decision points explicit. The script approach has proven successful in criminological research, having the merit of casting light on the modus operandi of offenders involved in different types of criminal activities, ranging from check forgery (Lacoste and Tremblay 2003) and theft of consumer electronic products (Ekblom and Sidebottom 2008) to child sex offending (Leclerc et al. 2011) and illegal waste activity (Tompson and Chainey 2011).

Criminologists have increasingly recognized that there are potential benefits from combining research on organized crime-and especially on trafficking activitieswith environmental criminology and situational crime prevention approaches (Bullock et al. 2010; Natarajan 2012), despite the severe difficulties in doing this (Laycock 2010; Von Lampe 2011). Script analysis in particular has been recently used to enhance the understanding of transit crimes (Von Lampe 2010; Chiu et al. 2011). By mapping the sequence of actions committed by offenders, it is possible to deconstruct the complex crime-commission process in order to identify not only the specific opportunities exploited by offenders but possible strategic intervention points. The state of the art in the use of script analysis to investigate trafficking activities is offered by Hancock and Laycock (2010). They proposed "the integrated organised crime script" for cases concerning drug or people trafficking, which operates at an even more thorough level of empirical specificity by distinguishing functions, script categories, and actions in the script scenes, as well as by stressing the pinch-points for interventions. This scripting model can improve our understanding of organized crimes (or their sub-species of transit crimes) in particular by distinguishing and addressing their script categories (or components parts)-namely the "primary criminal act" in the trafficking activity (from now on, crime), the "criminal lifestyle" (lifestyle, series of activities that are independent from any active offending process), and the "participation in/the access to criminal networks, groups or individuals" (network) (Hancock and Laycock 2010: 188). Indeed, all these three components, which are interrelated, need to exist because of the complexity of transit crimes. In the words of Hancock and Laycock (2010: 177), they represent "three separate but interrelated streams of opportunity for preventive/disruptive effort".

\section{Identifying criminal opportunities offered by the Internet}

The model proposed by Hancock and Laycock (2010) can be applied to wildlife trafficking to obtain a better understanding of the modus operandi of offenders involved in this under-investigated criminal activity. By following this model, it is possible to unfold the criminal activity by identifying a sequence of specific actions. Furthermore, since this research focuses on the criminal opportunities provided by the Internet, the distinction between three different script categories (crime, lifestyle, and network) is particularly useful. In fact, Internet usage might affect all of them, and such a distinction could serve as a guide for investigating how the Internet is exploited.

This study relies on Hancock and Laycock's organized crime script, with slight adaptations. Unlike the scheme developed by Hancock and Laycock, possible preventive responses have not been described in order to avoid exceeding the scope of this work, and the corresponding column has been eliminated. However, a column labelled Stages has been added to juxtapose the specific parts of the script (the actions where the Internet has been used) to the main stages of the trafficking flow as identified by the existing literature. Expanding on (Dalberg 2012: 11) and from the interviews done for this research, it was possible to distinguish between five main stages of wildlife trafficking (stages 1-5). Since criminal opportunities can be identified also in the activities that are antecedent and consecutive to the trafficking activity per se, two additional stages have been added (stages 0 and 6).

Stage 0: preparatory activities antecedent to the commission of wildlife trafficking

Stage 1: poaching, harvesting, or breeding of the animal/plant

Stage 2: intermediate passage through local

intermediaries/the domestic market

Stage 3: passage through regional intermediaries/ international traders

Stage 4: intermediate passage through local

intermediaries/the domestic market

Stage 5: distribution of the animal/plant/product

Stage 6: activities that are directly consequential or subsequent to the trafficking activity.

Note that the sequence of functions in the crime scene as identified by Cornish (1994) and used by Hancock and Laycock (2010) (preparation, entry, precondition, instrumental precondition, instrumental initiation, instrumental actualization, doing, post condition, and exit) has 
not been inserted in this script model to avoid making it over-complicated. In any case, it should be noted that there is no fixed correspondence between the sequence of traditional stages in wildlife trafficking and the sequence of functions (Lavorgna 2014). For instance, different preconditions for wildlife trafficking to occur could be needed in different stages.

\section{Data}

Data gathered from case studies have been analyzed within the crime script conceptual framework. The case studies are law enforcement operations in which the use of the Internet had a meaningful role. Relevant cases were initially identified through a preliminary keyword search of media sources, mainly Italian newspaper online archives (La Repubblica, Il Corriere della Sera), judicial databases (Dejure for Italian cases, Westlaw for US cases, and The Law Pages for UK cases), and through the reading of investigative reports (accessible in Italian or English). Additional cases were identified during interviews with law enforcement officers and experts. Primary documentary sources were also used (judicial transcripts and records from police investigations). A total of 25 cases investigated from 2007 to 2013 were selected out of 63 through convenience sampling for the analysis. Despite the limited generalizability of this sampling method, it allowed for the inclusion of data with particular characteristics of interest-i.e., the usage of the Internet in wildlife trafficking-and to select cases that have sufficient information to be studied with necessary depth.

Additional information was collected through face-toface, semi-structured interviews with Italian law enforcement officers (from CITES and NIRDA, the detective squad assigned to combat crimes against animals) and acknowledged experts (officials from wildlife NGOs). Specifically, both members of the Italian task force for Internet-mediated wildlife trafficking were interviewed. This task force was implemented following the last CITES Conferences of the Parties in 2010 and has been operational in Italy since 2011 . When selecting the interviewees, I relied on non-probability sampling methods, specifically purposive or judgment sampling and snowball sampling. I interviewed 2 experts and 4 law enforcement officials, for a total of about 10 hours.

There are limitations related to the data gathering strategies. First, the number of primary documentary sources used is limited because most relevant cases were under investigation or the trial was ongoing; however, data gathered through the semi-structured interviews with key informants helped to provide current, rich, and detailed knowledge. Second, most of the cases under consideration, even if transnational in nature, were prosecuted or investigated in Italy. Nonetheless, Italy has a core position in the so-called "Southern criminal hub" (EUROPOL 2009) and it is deeply involved in all the stages of wildlife trafficking.

\section{Script analysis and interpretation}

Following the script scheme outlined above, data have been organized into the following table. This script framework does not consider all the actions needed for wildlife trafficking, but only those in which the Internet has been used, as emerging from the case studies considered. Obviously, not all actions are present in all cases (Table 1).

The crime script for Internet-mediated wildlife trafficking illustrates a list of actions where the Internet has been used as a facilitator. Through this conceptual framework, it has been possible to identify five main types of criminal opportunities that the Internet provides for wildlife trafficking. Of course, a certain degree of overlap exists between the different types of criminal opportunities identified. Indeed, the proposed classification does not aim to pigeonhole behaviors into a certain category while precluding them from fitting elsewhere. Depending on the analytical needs, more fine-grained or coarse-grained classifications are certainly possible.

\section{Communicative and managerial opportunities:} communication is facilitated by the use of services such as emails, Skype, and instant messaging in forums both among traders and between them and (potential) customers. The Internet, however, does not merely provide an enhanced communication tool, but rather offers a unique framework to adjust the needs of the trafficking activity to meet changes in the marketplace to ensure efficiency in the trafficking chain. These opportunities affect mainly the script categories of "crime" and "lifestyle". Communicative and managerial opportunities are generally present in all stages of the criminal activity.

2. Informational and technical opportunities: the Internet provides access to useful information, ranging from tips on very practical aspects (such as how to feed parrots) to knowledge of the existing legal framework. Similarly, certain online services can provide solutions to specific problems. For instance, the Internet has been used to translate advertisements into other languages, to identify the location of rare plants in their country of origin in order efficiently to organize their harvest, and to track the shipment of animals, plants, and products when sent by mail. Informational and technical opportunities mainly impact the script category "crime", and they affect all stages of the trafficking activity-with the exception of stage 3 . 
Table 1 The crime script for Internet-related criminal opportunities in wildlife trafficking

\begin{tabular}{|c|c|c|c|}
\hline Stage & Script category & Action in which the internet has been used & Criminal opportunity \\
\hline \multirow{6}{*}{$\begin{array}{l}\text { Stage } 0 \text { : preparatory activities } \\
\text { antecedent to the commission } \\
\text { of wildlife trafficking }\end{array}$} & Crime lifestyle & $\begin{array}{l}\text { Discussion with other members of the criminal } \\
\text { net-work about the existing relevant legislation (email) }\end{array}$ & $\begin{array}{l}\text { Communicative and } \\
\text { managerial }\end{array}$ \\
\hline & Network lifestyle & $\begin{array}{l}\text { Maintenance of contacts with other members } \\
\text { of the criminal network (email, Skype) }\end{array}$ & $\begin{array}{l}\text { Communicative and } \\
\text { managerial }\end{array}$ \\
\hline & Lifestyle network & $\begin{array}{l}\text { Formation/existence of a criminal network } \\
\text { (email, dedicated forums) }\end{array}$ & Organizational and relational \\
\hline & Crime lifestyle network & $\begin{array}{l}\text { Discussion with criminal peers in order to exchange } \\
\text { information on new potential buyers (email) }\end{array}$ & Organizational and relational \\
\hline & Crime & $\begin{array}{l}\text { Identify the location of the animal/plant/product } \\
\text { via GPS and web mapping services (e.g. Google Maps) }\end{array}$ & Informational and technical \\
\hline & Lifestyle network & $\begin{array}{l}\text { Signal species that have been recently discovered/ } \\
\text { that are more rare and valuable (dedicated websites) }\end{array}$ & Promotional \\
\hline \multirow[t]{5}{*}{$\begin{array}{l}\text { Stage 1: poaching, harvesting, } \\
\text { or breeding of the animal/plant }\end{array}$} & Network lifestyle & $\begin{array}{l}\text { Share information about the location of the animal/ } \\
\text { plant/product in its natural environment (dedicated blogs) }\end{array}$ & $\begin{array}{l}\text { Communicative and } \\
\text { managerial }\end{array}$ \\
\hline & Crime lifestyle & $\begin{array}{l}\text { Agreement to send animals/plants/products via } \\
\text { regu-lar mail among supplier and intermediaries (emails) }\end{array}$ & $\begin{array}{l}\text { Communicative and } \\
\text { managerial }\end{array}$ \\
\hline & Crime lifestyle network & $\begin{array}{l}\text { Interaction with potential buyers (auction websites, } \\
\text { generalist commercial websites, dedicated commer-cial } \\
\text { websites, dedicated forums, reserved area in a website) }\end{array}$ & $\begin{array}{l}\text { Communicative and } \\
\text { managerial; organizational } \\
\text { and relational }\end{array}$ \\
\hline & Crime network & $\begin{array}{l}\text { Arrange sales of the specimen to intermediaries } \\
\text { (international auction websites) }\end{array}$ & Organizational and relational \\
\hline & Crime & $\begin{array}{l}\text { Buy traps and other instruments to poach animals } \\
\text { (commercial websites, dedicated forums) }\end{array}$ & Informational and technical \\
\hline \multirow[t]{2}{*}{$\begin{array}{l}\text { Stage 2: intermediate passage } \\
\text { through local intermediaries/ } \\
\quad \text { the domestic market }\end{array}$} & Crime lifestyle & $\begin{array}{l}\text { Discussion with other members of the criminal network } \\
\text { about how to ship animal/plant/product in small } \\
\text { packages with deceptive labels when sending them } \\
\text { through regular mail (email) }\end{array}$ & $\begin{array}{l}\text { Communicative and } \\
\text { managerial }\end{array}$ \\
\hline & Crime & Get information on relevant legislation & Informational and technical \\
\hline \multirow[t]{4}{*}{$\begin{array}{l}\text { Stage 3: passage through } \\
\text { regional intermediaries/ } \\
\text { international traders }\end{array}$} & Crime lifestyle & $\begin{array}{l}\text { Discussion with other members of the criminal network } \\
\text { about how to ship animal/plant/product in small } \\
\text { packages with deceptive labels when sending them } \\
\text { through regular mail (email) }\end{array}$ & $\begin{array}{l}\text { Communicative and } \\
\text { managerial }\end{array}$ \\
\hline & Crime network & $\begin{array}{l}\text { Agreement to exclude local intermediaries who hesitate } \\
\text { due to fear of prosecution over illegal activities (email) }\end{array}$ & Organizational and relational \\
\hline & Crime network & $\begin{array}{l}\text { Arrange sales of the specimen to intermediaries } \\
\text { (international auction websites) }\end{array}$ & Organizational and relational \\
\hline & Crime lifestyle & $\begin{array}{l}\text { Advertise availability of new animals/plants/products } \\
\text { (dedicated forums) }\end{array}$ & Promotional \\
\hline \multirow{6}{*}{$\begin{array}{l}\text { Stage 4: intermediate passage } \\
\text { through local intermediaries/ } \\
\quad \text { the domestic market }\end{array}$} & Network lifestyle & $\begin{array}{l}\text { Share information about the location of the animal/plant/ } \\
\text { product in its natural environment (dedicated blogs) }\end{array}$ & $\begin{array}{l}\text { Communicative and } \\
\text { managerial }\end{array}$ \\
\hline & Crime lifestyle & $\begin{array}{l}\text { Discuss prices/meeting places in the physical world to } \\
\text { complete the deal (emails) }\end{array}$ & $\begin{array}{l}\text { Communicative and } \\
\text { managerial }\end{array}$ \\
\hline & Crime lifestyle & $\begin{array}{l}\text { Discussion with other members of the criminal network } \\
\text { about how to ship animal/plant/ product in small } \\
\text { packages with deceptive labels when sending them } \\
\text { through regular mail (email) }\end{array}$ & $\begin{array}{l}\text { Communicative and } \\
\text { managerial }\end{array}$ \\
\hline & Crime lifestyle & $\begin{array}{l}\text { Agreement among criminal peers to physically meet } \\
\text { and exchange animals/plants/products (private } \\
\text { messaging in dedicated commercial websites, email) }\end{array}$ & $\begin{array}{l}\text { Communicative and } \\
\text { managerial }\end{array}$ \\
\hline & Crime lifestyle & $\begin{array}{l}\text { Agreement to send animals/plants/products via } \\
\text { regular mail among supplier/intermediaries (emails) }\end{array}$ & $\begin{array}{l}\text { Communicative and } \\
\text { managerial }\end{array}$ \\
\hline & Crime & Sell animals/plants/products on auction websites (e.g. eBay) & $\begin{array}{l}\text { Communicative and } \\
\text { managerial }\end{array}$ \\
\hline
\end{tabular}


Table 1 The crime script for Internet-related criminal opportunities in wildlife trafficking (Continued)

\begin{tabular}{|c|c|c|c|}
\hline & Crime lifestyle network & $\begin{array}{l}\text { Interaction with potential buyers (auction websites, } \\
\text { generalist commercial websites, dedicated commer-cial } \\
\text { websites, dedicated forums, reserved area in a website) }\end{array}$ & $\begin{array}{l}\text { Communicative and } \\
\text { managerial; organizational } \\
\text { and relational }\end{array}$ \\
\hline & Lifestyle network & $\begin{array}{l}\text { Forward emails from suppliers who can fulfill orders } \\
\text { from potential customers (email) }\end{array}$ & $\begin{array}{l}\text { Communicative and } \\
\text { managerial; organizational } \\
\text { and relational }\end{array}$ \\
\hline & Lifestyle network & $\begin{array}{l}\text { Inform potential clients/intermediaries on updated } \\
\text { prices (emails) }\end{array}$ & $\begin{array}{l}\text { Communicative and } \\
\text { managerial; promotional }\end{array}$ \\
\hline \multirow[t]{16}{*}{$\begin{array}{l}\text { Stage 4: intermediate passage } \\
\text { through local intermediaries/the } \\
\text { domestic market (continued) }\end{array}$} & Crime network & $\begin{array}{l}\text { Agreement to exclude local intermediaries who } \\
\text { hesi-tate due to fear of prosecution over illegal } \\
\text { activities (email) }\end{array}$ & Organizational and relational \\
\hline & Network crime & Search for new suppliers (emails, dedicated forums) & Organizational and relational \\
\hline & Crime & $\begin{array}{l}\text { Arrange sales of the animal/plant/product to final } \\
\text { buyers (international auction websites) }\end{array}$ & Organizational and relational \\
\hline & Crime network & $\begin{array}{l}\text { Put costumers directly in contact with intermediaries } \\
\text { or suppliers (emails) }\end{array}$ & Organizational and relational \\
\hline & Crime & $\begin{array}{l}\text { Use of Google translator to post announcements } \\
\text { in different languages }\end{array}$ & Informational and technical \\
\hline & Crime & $\begin{array}{l}\text { Get information on specific species (on their } \\
\text { morphology and on how to breed them) }\end{array}$ & Informational and technical \\
\hline & Crime & Get information on relevant legislation & Informational and technical \\
\hline & Crime & $\begin{array}{l}\text { Automated sell of the animal/plant/product } \\
\text { (order form on dedicated commercial website) }\end{array}$ & Informational and technical \\
\hline & Crime & Monitor the delivery via regular mail & Informational and technical \\
\hline & Crime & Payment (prepaid cards to be recharged online) & Informational and technical \\
\hline & Crime lifestyle & $\begin{array}{l}\text { Contact directly consumers reassuring them that } \\
\text { without documents the price is significantly lower } \\
\text { (emails, dedicated forum) }\end{array}$ & Persuasive \\
\hline & Crime lifestyle & $\begin{array}{l}\text { Discuss with potential customers the absence of } \\
\text { required documentation (emails) }\end{array}$ & Persuasive \\
\hline & Crime lifestyle & $\begin{array}{l}\text { Reassure customers about the quality of the animal/ } \\
\text { plant/product (commercial website, auction website) }\end{array}$ & Persuasive \\
\hline & Crime lifestyle & $\begin{array}{l}\text { Attempt to cover the criminal act by claiming that } \\
\text { animals/plants/products have been imported in the } \\
\text { past with CITES certificates but they have been all } \\
\text { given to others (dedicated website) }\end{array}$ & Persuasive \\
\hline & Lifestyle network & $\begin{array}{l}\text { Advertising fairs and exhibitions (dedicated websites, } \\
\text { dedicated forums) }\end{array}$ & Promotional \\
\hline & Crime lifestyle & $\begin{array}{l}\text { Advertise availability of new animals/plants/products } \\
\text { (dedicated forums) }\end{array}$ & Promotional \\
\hline \multirow[t]{7}{*}{$\begin{array}{l}\text { Stage 5: distribution of the } \\
\text { animal/plant/product }\end{array}$} & Crime lifestyle & $\begin{array}{l}\text { Discuss prices/meeting places in the physical world } \\
\text { to complete the deal (emails) }\end{array}$ & $\begin{array}{l}\text { Communicative and } \\
\text { managerial }\end{array}$ \\
\hline & Crime lifestyle & $\begin{array}{l}\text { Order/reserve a specific animal/plant/product } \\
\text { (com-mercial websites, dedicated forums, email) }\end{array}$ & $\begin{array}{l}\text { Communicative and } \\
\text { managerial; organizational } \\
\text { and relational }\end{array}$ \\
\hline & Crime & Monitor the delivery via regular mail & Informational and technical \\
\hline & Crime & Payment (prepaid cards to be recharged online) & Informational and technical \\
\hline & Crime lifestyle & $\begin{array}{l}\text { Contact directly consumers reassuring them that } \\
\text { without documents the price is significantly lower } \\
\text { (emails, dedicated forum) }\end{array}$ & Persuasive \\
\hline & Crime lifestyle & $\begin{array}{l}\text { Discuss with potential customers the absence } \\
\text { of required documentation (emails) }\end{array}$ & Persuasive \\
\hline & Crime lifestyle & $\begin{array}{l}\text { Reassure customers about the quality of the animal/ } \\
\text { plant/product (commercial website auction website) }\end{array}$ & Persuasive \\
\hline
\end{tabular}




\section{Table 1 The crime script for Internet-related criminal opportunities in wildlife trafficking (Continued)}

\begin{tabular}{|c|c|c|c|}
\hline \multirow[t]{3}{*}{$\begin{array}{l}\text { Stage 6: activities that are directly } \\
\text { consequential or subsequent to } \\
\text { the trafficking activity }\end{array}$} & Lifestyle network & $\begin{array}{l}\text { Buy accessories/ share videos and pictures in cases } \\
\text { of zooerasty where wildlife animals are involved } \\
\text { (dedicated forums, deep web) }\end{array}$ & $\begin{array}{l}\text { Informational and } \\
\text { technical; organizational } \\
\text { and relational }\end{array}$ \\
\hline & Crime & Monitor the delivery via regular mail & Informational and technical \\
\hline & Crime Lifestyle & $\begin{array}{l}\text { Attempt to cover the criminal act by claiming that } \\
\text { animals/plants/products have been imported in } \\
\text { the past with CITES certificates but they have been } \\
\text { all given to others (dedicated website) }\end{array}$ & Persuasive \\
\hline
\end{tabular}

3. Organizational and relational opportunities: the use of the Internet facilitates the internal organization of criminal networks; in particular, it can reduce the organizational layers. Indeed, some organizational layers now are no longer necessary; in particular, a distinction between international and local intermediaries as expected in stages 3 and 4 was generally missing in the cases observed, where the same people were involved in both cross-border trades and relationships with final buyers, thus acting as local retailers. This mainly depends on the fact that the Internet can affect the external interactions of criminal networks, facilitating the relationships among them as well as their contacts with (potential) buyers. Thus, the Internet provides an irreplaceable platform to expand offenders' networks of relationships by building new business ties with actors involved in the trafficking chain in various capacities. Organizational and relational opportunities mainly affect the script categories "crime" and "network". They have been found in all stages of the criminal activity apart from Stage 2: the passage through local intermediaries at the beginning of the trafficking chain.

4. Promotional opportunities: events in the physical world such as fairs and exhibitions and the availability of animals, plants, and products to be sold online are advertised via the Internet. Promotional opportunities affect stages 0, 3, and 4 of wildlife trafficking and in particular the script category "lifestyle".

5. Persuasive opportunities: the Internet can be used to reassure (potential) buyers about the reliability of the trade and the validity of the animal, plant, and product sold. For instance, in one case regarding caviar smuggling, a semblance of legality was attained by stating that the caviar had been purchased as a gift from the Russian wife of the advertiser. In another case, the criminal activity was disguised by the existence of outdated legal documentation. Persuasive opportunities have been found in the final stages of the trafficking (stages 4, 5, and 6) and affect the "crime" and the "lifestyle".
From the case studies and from additional information gathered during the interviews, it becomes clear how the Internet, as one interviewee reported, has not only "entailed an explosion of the phenomenon", but also redesigned several stages of trafficking activity and the modalities through which some of them are carried out. Two interviewees claimed that an "evolution" of this criminal market has occurred, and one stressed how the Internet is not only a crime facilitator but it also made possible the criminal activity itself by serving as "the real instrument for the [criminal] organization to work". However, the extent to which the use of the Internet affects wildlife trafficking depends on the specific phase in the trafficking chain. From the script framework and particularly from the Stage column, it clearly emerges that the Internet plays a major role in the preparation of the criminal activity and in the final parts of wildlife trafficking - namely the transit through local intermediaries in the destination countries and the distribution stage. In particular, regarding the new criminal opportunities in the distribution stage, the criminal market in wildlife closely resembles the flexible "cyber-bazaar" in counterfeit goods described by (Treadwell 2012: 187). In counterpoint, apart from its obvious usage as a communication tool, the Internet does not seem to have affected the opportunity structure in the initial stages of the criminal activity. This is because most poachers aim to supplement their income by relying on traditional social and economic structures to sell their products. In only a couple of cases has the Internet allowed for the planning of the criminal activity directly from the destination country: for instance, in a case of trafficking in cacti, the use of new technologies completely eliminated the initial stages of the criminal activity by allowing them to be planned entirely from the destination country.

Case study \#1. Eleven persons were investigated for trafficking rare cacti from Chile, Argentina, and Peru (Appendixes I and II CITES). The perpetrators geo-referenced and identified the position of specific species via the Internet before going to the location to harvest them. Cacti were then sold on dedicated forums and websites to cactus lovers in the destination country ${ }^{\mathrm{d}}$. 
The order of certain phases can also be shuffled, as illustrated in the following case where the poaching can happen at a later stage, after the interaction with the buyer, when he/she orders a specific animal, plant, or product.

Case study \#2. Specific types of turtles (Appendix I CITES) were ordered from the Internet and then poached directly from their natural environment (in Sardinia). Apparently, the supply was insufficient to satisfy the number of requests received after online announcements, so the Internet was again used to search for new suppliers ${ }^{\mathrm{e}}$.

In the Action column of the script framework, the modalities through which the Internet was used are identified. In particular, the Internet services through which the trafficking activity has been carried out as well as the types of cyber-hotspots used are specified. They are not only "convergence settings" (Felson 2006) as identified by Soudijn and Zegers (2012)-i.e., online places where potential offenders can easily meet each other-but rather loci where interactions among all actors involved in wildlife trafficking are facilitated. Apart from generalist commercial and auction websites, there are a number of dedicated commercial websites (such as ItalyPet), forums, and blogs. Furthermore, people interacting in cyberspace often meet in the physical world to conclude their deals, so in many instances cyber-hotspots are better described as extensions of traditional hotspots. A clear example is provided by the fact that fairs and exhibitions where live animals and plants are sold are often advertised in conjunction with the online selling.

So far, the analysis has focused on the impact the Internet has on how criminal acts are carried out. The Script Category column of the script framework, however, shows that the crime is only one of the parallel processes taking place in complex criminal activities, together with the criminal lifestyle and the participation in criminal networks. By including these aspects in the analysis, it is possible to describe how the use of the Internet changes the relationships between the actors involved in wildlife trafficking. Greater ease in communications as well as new managerial and organizational opportunities allow for highly flexible and fluid organizational forms, which are capable of adapting to contingent needs. In several cases, everything was managed via the Internet, so that it was possible to react promptly to specific buyers' needs-for instance, by putting them in contact with partner suppliers or by finding new suppliers to meet buyers' requests. In many cases, thanks to this flexibility it was possible to bypass local intermediaries. As a consequence, no case exhibited all five stages identified by Dalberg (2012).
Case study \#3. Offender A, an American shop owner, sold sperm whale teeth and narwhal tusks (Appendix I CITES) to tourists and a regional intermediary, offender B. Offender B, in particular, acted as the US-based distributor for offender C, a Ukraine-based dealer selling the product to overseas customers and to several other smugglers. Offender A decided to expand his business by selling the products to online buyers from all over the world. Some of the buyers were likely to be regional intermediaries in other (European) countries given the large quantities of products bought. After a "flurry of emails" (as reported in the judicial file), offender A decided to bypass offender B (who displayed doubts regarding going on with the criminal activity) and to sell directly to offender $C$.

Many investigations highlight the fact that relationships between suppliers, intermediaries, and traders are stable over time. Indeed, in a couple of cases, it was possible to note that traders and suppliers were careful not to get in each other's way and respected a certain division of labour even when there was the possibility to have direct contacts with buyers, probably in order to maintain good relations with intermediaries for future deals.

Case study \#4. The core of the criminal networktrafficking mainly turtles (Appendix I CITES) but also cats and dogs-was formed by offender A, offender B, and offender C. Offender A was in charge of posting advertisements on dedicated commercial websites and relations with customers, while offenders B and C were the suppliers (sometimes acting as regional intermediaries, sometimes directly as poachers). The poaching and the illegal trade were rather intense, as signaled by the impressive amount of turtles advertised online. Prices were particularly low (about half of the price in the legal market). Departing from this central triad, a complex criminal network emerged during the investigation. Even if online announcements were done under different names and they referred to different parts of Italy, mobile numbers were the same. Furthermore, some of the customers seemed to be particularly active: in connection to that, CITES officials suggested that they could be intermediaries themselves ${ }^{\mathrm{g}}$.

\section{Additional findings}

Trafficking wildlife via the Internet is perceived as a low risk activity, to the point that in one case, according to records from police investigations, it was evident that the trafficking continued even when the perpetrators were conscious that some co-offenders were targeted by 
law enforcement ${ }^{\mathrm{h}}$. Similarly, an interviewee underlined that "for the time being, these groups do not take many precautions. They are conscious that some controls exists, but also that they are sporadic". Regarding the cyber-hotspots identified, what was noticeable is that, in almost all cases, criminal opportunities arose from the so-called "surfing web", open to the wider public; thus, the demand for contacting potential collectors of specific species overcomes the need for discretion in the trafficking activity. This is true especially in the case of illegal sales of animals, plants, and products that might be confused by non-experts as legally marketable items. It is safe to say that differences in the degree of concealment of wildlife trafficking activity in cyberspace are better explained by the different perceptions of the seriousness of the criminal act (in terms of what is trafficked) than by the degree of illegality of the market (forbidden by the law tout court, rather than possibly legally marketable under different circumstances).

The Internet is exploited for wildlife trafficking by three main categories of actors: merchants that are involved in legal wildlife trade, full-timers for whom wildlife trafficking is the main source of income, and people involved in "extemporaneous" criminal activities (to use the word of one of the interviewees). In this last (more rare) case, individuals or couples run small-scale criminal trades that depend on transient opportunitiesfor instance, the poaching of a couple of wildlife animals during an exotic holiday.

In most cases, Internet-mediated wildlife trafficking is intermingled with legal markets. On the one hand, legitimate companies provide legal coverage for illegal trades; on the other, many legitimate traders in wildlife and pets simply decide to expand their businesses by embracing criminal opportunities in the online realm as an easy and safe way to increase their profits. The following two cases exemplify this.

Case study \#5. Black caviar (Appendix I CITES) was illegally traded by Russian couriers from the Russian Federation to Italy through Moldova thanks to the legal coverage of a legitimate Italian company operating in that area. Once in Italy, the caviar was sold online by Italian advertisers through dedicated websites (in one of these there was also an order form to make the purchase completely automated) and online auctions (eBay) well below market prices ${ }^{\mathrm{i}}$.

Case study \#6. Two out of 11 persons investigated for trafficking rare cacti (Appendixes I and II CITES) worked in a garden center. Because of their jobs, they had genuine certificates of origin for cacti from Chile that were more than 10 years old, and they were trying to use these to cover the illegality of their current trades. They also attempted to conceal the criminal nature of their recent activities by publicly denying on a dedicated website (run by them) that they ever traded endangered species and by claiming that the cacti regularly imported in the past with CITES certificates had all been given to others ${ }^{j}$.

While in most cases traders simply expanded their business activity over the Internet, one interviewee underlined that some trades (for instance, pets sold via the Internet) are so profitable that many persons have left their legitimate work to dedicate their time fully to the criminal market. Indeed, as regards Internet-mediated wildlife trafficking, the case studies highlight that the actors behind the scenes are often persons professionally involved in large-scale criminal trades. In some of the law enforcement operations, the same people were behind various announcements, even if they appeared with different names. Furthermore, they claimed to be able to provide a broad range of animals from different geographical areas, which suggests the existence of criminal networks with stable international connections.

Media and investigative reports often relate wildlife trafficking to transnational organized crime and create the idea that this transit crime is run by sophisticated criminal groups. Indeed, there are also organized criminal organizations specializing in wildlife trafficking, which are involved as intermediaries in profitable and large scale types of trades, especially in the initial stages of the trafficking flow. There are no specific elements that indicate that these organized criminal groups are facilitated by criminal opportunities that are specifically provided by the Internet. On the other hand, new technologies have allowed the entrance into the wildlife criminal market of very loose organizations. Where a structured criminal association was once needed to commit cross-border crimes, in many instances this is no longer the case. For instance, both payment and product delivery can be made from a safe distance through online banking and automated postal services. Sometimes only specific parts of the trafficking chain need the involvement of professional, organized criminal groups. According to a couple of interviewees, the Internet has facilitated the creation of contacts with some of these criminal actors-for instance, with groups operating in the Netherlands that are specialized in forging documents.

Even if in certain cases many people were involved (often about 10 people, though one investigation charged 27 people), in most instances the networks running the criminal business via the Internet were composed of very few people, often couples or small family groups (for instance father, son, and the son's partner). One would expect a certain degree of sophistication from criminal networks running wildlife trafficking, given its intrinsic complexity. 
Nonetheless, the use of the Internet has allowed very loose organizations and even individuals to enter the market and to be equally (if not more) efficient. The technical skills required are low, and the essential information needed to carry out the trade can be easily accessed online by beginners. It should be noted that in the case studies criminal networks operating via the Internet were often intergenerational, and in cases where genders were specified, approximately one fourth of the identifiable investigated or convicted persons were women.

Case study \#7. Capuchin monkeys (Appendix II CITES) were trafficked from West Africa to Italy. Specifically, they were delivered in Milan by members of the West and Central African communities and in Padua by a Belgian couple. Online announcements were hosted by a Spanish website ${ }^{k}$.

Case study \#8. The defendant was found with $€ 70,000$ euros cash in his apartment. He was selling different types of animals via the Internet. Given their different native habitats, it is likely he had several suppliers. During the search, sloths, aardvarks, Asian bats, snowy owls, flying foxes, and venomous snakes were found.

Finally, it should be noted that the Internet is linked to wildlife trafficking in many cases of fraud. Even though not specifically considered in the analysis, all interviewees underlined how many online announcements (in commercial websites or sent as email spam) promise animals for free or at very low prices. Those announcements generally offer animals whose trade is manifestly illegal such as monkeys or tigers, but also expensive fullblood dogs, allegedly sent from Western and Central Africa. However, victims are then asked to pay unexpected expenses for the transport. Obviously, animals are never delivered.

\section{Conclusions}

The previous sections have shown how the use of the Internet has affected the organization of wildlife trafficking, as regards both the carrying out of the criminal activity and the patterns of relations in and among criminal networks. Thus, for wildlife traffickers, the Internet does not seem to be used only as a communication tool (e.g., through Skype and emails) but it has also affected this criminal market in a much more extensive way by making it a hybrid market that combines the traditional social and economic opportunity structures with the new ones provided by the Internet.

Some general themes can be identified. First, the Internet has boosted wildlife trafficking in a substantial way by lowering the barriers to entry into criminal markets and opening the way for new criminal actors. Secondly, as hypothesized by Brenner (2002) and Wall (2007: 39ff), the transformative impact of the Internet has affected the organization of criminal networks and the division of criminal labor. Individuals and looser groups can now carry out complex and far-reaching activities, given their greater potential control over the criminal process. Instead of being organized by traditional hierarchical organizational structures, Internet-mediated wildlife trafficking is run by fluid networks adapting to transient criminal opportunities. At the same time, some organizational layers have been eliminated, and the Internet has re-configured relations among suppliers, intermediaries, and buyers. Not only does it facilitate communication and exchange of information, but the Internet also affects how trust among them is earned. Finally, in most cases Internet-mediated wildlife trafficking comprises routinized criminal acts carried out by professional offenders for whom this transit crime is a major source of income and indeed a way of life: they may have other sources of income, but their economic interests are primarily connected to criminal profits, so that their lives are organized around a criminal way of behaving (Mack 1972: 44-45; Hobbs 1995). They do not rely on sporadic opportunities, but they are rationally geared to the needs of their criminal activity, which depends to a significant degree on their handling of "the technical problems of crime-which are the problems of combating social control in its widest sense" (McIntosh 1975: 73). In the Internet environment, new technical problems have to be overcome.

As has already been underlined, an important innovation in wildlife trafficking can be attributed to the new actors that have entered the market as traders, especially young collectors. Most cyber-hotspots act as fora where not only persons with peculiar interests can more easily "meet", but also potential sellers and buyers can contact each other. People interacting in these "places" usually share the same types of passions and tend to recognize themselves as part of the same social network. Furthermore, no matter how highly specialized or segmented the market in trafficked animals, plants, or products is, it is much easier to find potential buyers or sellers online than in the physical world. From this point of view, the Internet seems to have further boosted the importance of niche criminal markets.

The use of crime scripts does raise considerations when applied to complex criminal activities such as wildlife trafficking. Moreto and Clarke (2013) have recently dealt with these issues and concluded that, despite the impediments, script analysis has a role to play in the study of complex transnational crimes if we recognize that this role is necessarily more limited than in simpler criminal activities. However, most of the problems addressed by Moreto and Clarke are related to the use of script analysis for situational crime prevention purposes, 
while in this study script analysis serves only as a framework for identifying an opportunity structure.

The identification of the specific criminal opportunities provided by the Internet for transit crimes is a challenging task. Nonetheless, this is a necessary step for understanding the way in which the use of the Internet has affected criminal markets, and a necessary starting point to enhance crime prevention and disruption while maintaining a balance between openness and security on the Internet.

\section{Endnotes}

${ }^{a}$ The notion of transit crimes has been developed as an alternative concept to the one of (transnational) organized crime (Kleemans 2007). It allows to ignore organized crime activities-such as the ones involving the control of economic sectors or regions-that characterize only certain experiences of organized crime and to focus on those one which appear to be the primary businesses of organized crime-i.e., trafficking activities.

${ }^{\mathrm{b}}$ In the EU, the CITES has been implemented by Council Regulation N. 338/1997 and Commission Regulation 865/2006. The EU Wildlife Trade Regulations, directly applicable in all Member States, provide a four levels, stricter control over wildlife trade (Engler and Parry-Jones 2007).

${ }^{\mathrm{c}} \mathrm{So}$ far, only few concrete actions have been taken to counter wildlife trafficking via the Internet. For Instance, eBay instituted a global ban on ivory sales (IFAW 2012). From a legal perspective, however, the only stance on this issue has been taken at the 58th meeting of the CITES Conference of the parties in 2010, when a resolution was adopted, asking - among other things - to "establish, at the national level, a unit dedicated to investigating wildlife crime linked to the Internet or incorporate wildlife trade issues into existing units that investigate or monitor computer o cyber-crime" (Resolution 11.3, Rev. CoP15).

${ }^{\mathrm{d}}$ CITES investigative material, 2007.

${ }^{\mathrm{e}}$ CITES investigative material, 2010.

${ }^{\mathrm{f}}$ Judicial material from the US Court of Appeals, First Circuit, 2012.

${ }^{\mathrm{g}}$ CITES investigative material, 2011.

${ }^{\mathrm{h}}$ CITES investigative material, 2011.

${ }^{\mathrm{i} C I T E S}$ investigative material, 2011.

jCITES investigative material, 2007.

${ }^{\mathrm{k}}$ Journalistic inquiry from La Repubblica, April 4, 2007.

${ }^{\mathrm{l}}$ Media news from Il Corriere della Sera, March 26, 2010 and interview material.

\section{Competing interests}

The author declare that she has no competing interests.

\section{Acknowledgements}

I would like to thank my interviewees, the anonymous referees for their helpful comments, and Mark Beittel for his precious support. I would also like to express my sincere gratitude to Jerry Ratcliffe for his constructive editorial suggestions. Special thanks go to Ronald Clarke for his kind guidance and encouragement
Received: 27 August 2013 Accepted: 7 January 2014

Published online: 15 May 2014

\section{References}

Brenner, SW. (2002). Organized cybercrime? How cyberspace may affect the structure of criminal relationships. North Carolina Journal of Law and Technology, 4(1), 1-50.

Bullock, K, Clarke, RV, \& Tilley, N. (2010). Introduction. In K Bullock, RV Clarke, \& N Tilley (Eds.), Situational Prevention of Organised Crimes (pp. 1-16). Devon: Willan Publishing.

Chiu, YN, Leclerc, B, \& Townsley, M. (2011). Crime script analysis of drug manufacturing in clandestine laboratories. British Journal of Criminology, 51(2), 355-374.

Cook, D, Roberts, M, \& Lowther, J. (2002). The International Wildlife Trade and Organised Crime. A review of the evidence and the role of the UK. Regional Research Institute, University of Wolverhampton. Report, Woking, UK: WWF.

Cooper, S. (2006). Inside the cartels that built empires and destroyed species. Seedmagazine. http://seedmagazine.com/content/article/the_caviar_kings/ Accessed on 8 October 2013.

Cornish, DB. (1994). The Procedural Analysis of Offending and Its Relevance for Situational Prevention. In RV Clarke (Ed.), Crime Prevention Studies 3 (pp. 151-196). New York: Criminal Justice Press.

Dalberg. (2012). Fighting Illicit Wildlife Trafficking: A Consultation with Governments. Report. Gland (Switzerland): WWF.

Ekblom, P, \& Sidebottom, A. (2008). What do you mean, "Is it secure?" Redesigning language to be fit for the task of assessing the security of domestic and personal electronic goods. European Journal on Criminal Policy and Research, 14, 61-87.

EMCDDA. (2013). EU drug markets report: a strategic analysis. European Monitoring Center for Drugs and Drug Addiction. Luxembourg: Publications office of the European Union.

Engler, M, \& Parry-Jones, R. (2007). Opportunity or threat. The role of the European Union in global wildlife trade. Report, Brussels: TRAFFIC Europe.

EUROPOL. (2009). EU Organized Crime Threat Assessment. OCTA. Report. The Hague: European Police Office.

EUROPOL. (2011). Internet facilitated organized crime. IOCTA (abridged). Report. The Hague: European Police Office.

Felson, M. (2006). The ecosystem for organized crime. HEUNI paper N. 26. Helsinki: Heuni.

Felson, M, \& Clarke, RV. (1998). Opportunity makes the thief: Practical theory for crime prevention. Police Research Series, Paper 98. London: Home Office.

Hancock, G, \& Laycock, G. (2010). Organised crime and crime scripts: prospects for disruption. In K Bullock, RV Clarke, \& N Tilley (Eds.), Situational Prevention of Organised Crimes (pp. 172-193). Devon: Willan Publishing.

Hobbs, D. (1995). Bad Business. Professional Crime in Modern Britain. Oxford: Oxford University Press.

Hughes, D. (2002). The use of new communication and information technologies for the sexual exploitation of women and children. Hastings Women's Law Journal, 13(1), 127-146.

IFAW. (2005). Caught in the Web: Wildlife trade on the Internet. Report, London: International Fund for Animal Welfare.

IFAW. (2008). Criminal Nature: The Global Security Implications of the Illegal Wildlife Trade. Report, Yarmouth Port, MA: International Fund for Animal Welfare.

IFAW. (2012). Killing with keystrokes 2.0: IFAW's investigation into the European online ivory trade. Report, Yarmouth Port, MA: International Fund for Animal Welfare.

Interpol. (2013). Project Web. An investigation into the ivory trade over the Internet within the European Union. Lyon: Interpol.

Kleemans, ER. (2007). Organized crime, transit crime, and racketeering. Crime \& Justice, 35, 163-215.

Lacoste, J, \& Tremblay, P. (2003). Crime and innovation: a script analysis of patterns in check forgery. In MJ Smith MJ, \& DB Cornish (Eds.), Theory for practice in situational crime prevention studies (vol. 16). Monsey: Criminal Justice Press.

Lavorgna, A. (2014). Script analysis of complex criminal activities: investigating the use of the Internet as a facilitator for offline transit crimes. SAGE Research Methods Cases. Sage Publications. Forthcoming.

Laycock, G. (2010). Foreword. In RV Clarke \& N Tilley (Eds.), K Bullock K. Situational Prevention of Organised Crimes. Devon: Willan Publishing.

Leclerc, B, Wortley, R, \& Smallbone, S. (2011). Getting into the script of adult child sex offenders and mapping out situational prevention measures. Journal of Research in Crime and Delinquency, 48, 209-237. 
Legambiente, Osservatorio Nazionale Ambiente e Legalità. (2010). Ecomafia. Le storie e i numeri della criminalità ambientale. Report. Milano: Edizioni Ambiente.

Mack, JA. (1972). The able criminal. The British Journal of Criminology, 12(1), 44-55.

Mayhew, P, Clarke, RV, Sturman, A, \& Hough, M. (1976). Crime as Opportunity. Home Office Research Study N.34. London: Her Majesty's Stationery Office.

McIntosh, M. (1975). The organization of crime. London: The Macmillan Press. Moreto, WD, \& Clarke, RV. (2013). Script Analysis of the Transnational Illegal Market in Endangered Species. Dream and Reality. In B Lecrec \& R Wortley (Eds.), Cognition and Crime: Offender Decision-Making and Script Analysis. London: Routledge.

Natarajan, M. (2012). A rational choice analysis of organized crime and trafficked goods. In N Tilley \& G Farrell (Eds.), The reasoning criminologist. Essays in honour of Ronald V. Clarke (pp. 194-204). Routledge: Abingdon.

Pires, S, \& Clarke, RV. (2012). Are parrots CRAVED? An analysis of parrot poaching in Mexico. Journal of Research in Crime and Delinquency, 49(1), 129-146.

Sollund, R. (2011). Expressions of speciesism: the effects of keeping companion animals on animal abuse, animal trafficking and species decline. Crime, Law and Social Change, 55(5), 437-451.

Soudijn, MRJ, \& Zegers, BCH. (2012). Cybercrime and virtual offender convergence settings. Trends in organized crime, 15(2-3), 111-129.

Sykiotou, AP. (2007). Trafficking in human beings: Internet recruitment. Strasbourg: Directorate General of Human Rights and Legal Affairs, Council of Europe.

Tompson, L, \& Chainey, S. (2011). Profiling illegal waste activity: using crime scripts as a data collection and analytical strategy. European Journal of criminal Policy and Research, 17(3), 179-201.

Treadwell, J. (2012). From the car boot to booting it up? eBay, online counterfeit crime and the transformation of the criminal marketplace. Criminology and Criminal Justice, 12(2), 175-191.

Troiano, C. (2011). Rapporto Zoomafia 2011. Crimini seriali a danno degli animali. Report. Roma: LAV.

Von Lampe, K. (2010). Preventing organized crime: the case of contraband cigarettes. In K Bullock, RV Clarke, \& N Tilley (Eds.), Situational Prevention of Organised Crimes (pp. 35-58). Devon: Willan Publishing.

Von Lampe, K. (2011). The application of the framework of situational crime prevention to 'organized crime'. Criminology and Criminal Justice, $11(2), 145-163$

Wall, DS. (2007). Cybercrime: The transformation of crime in the information age. Cambridge: Polity.

Walsh, C. (2011). Drugs, the internet and change. Journal of Psychoactive Drugs, $43(1), 55-63$

Warchol, GL. (2004). The international illegal wildlife trafficking. Criminal Justice Studies: a Journal of Crime, Law and Society, 17(1), 57-73.

Warchol, GL, Zupan, LL, \& Clack, V. (2003). Transnational Criminality: an analysis of the illegal wildlife market in Southern Africa. International Criminal Justice Review, 13(1), 1-27.

Williamson, DF. (2004). Tackling the Ivories: The Status of the US Trade in Elephant and Hippo Ivory. Report, Washington, DC: TRAFFIC North America.

Wu, J. (2007). World without borders: wildlife trade on the Chinese-language internet. TRAFFIC Bulletin, 21(2), 75-84.

Wyatt, T. (2009). Exploring the organization of Russia Far East's illegal wildlife trade: two case studies of the illegal fur and illegal falcon trades. Global Crime, 10(1-2), 144-154

Zimmerman, ME. (2003). The black market for wildlife: combating transnational organized crime in the illegal wildlife trade. Vanderbilt Journal of transnational Law, 36, 1657-1689.

doi:10.1186/s40163-014-0005-2

Cite this article as: Lavorgna: Wildlife trafficking in the Internet age. Crime Science 2014 3:5.

\section{Submit your manuscript to a SpringerOpen ${ }^{\circ}$ journal and benefit from:}

- Convenient online submission

- Rigorous peer review

- Immediate publication on acceptance

- Open access: articles freely available online

- High visibility within the field

- Retaining the copyright to your article

Submit your next manuscript at $\gg$ springeropen.com 